$2(29) / 2015$

\author{
Krzysztof Jakubiak \\ Uniwersytet Gdański \\ k.jakubiak@uwm.edu.pl
}

\title{
Od idei poznania dziecka do pedologii jako nauki o dziecku
}

\section{Summary \\ From the idea of child recognition to pedology as the theory of children's behaviour and development}

The child and childhood as socio-pedagogical categories are studied and described in the relatively recent pedagogical literature. Indeed systematic scientific reflection on childhood began in the mid nineteenth century and was connected with the contemporary development of child psychology and later pedology as the theory of the child. The article intends to develop the thesis that pedology had its origins in the European tradition of modern era pedagogy and, what is more important, that it was referring to the mid-eighteenth century postulates which proclaimed the need to know the child. Therefore, the main aim of this theory, which has been developing in Europe and the United States of America since the late nineteenth century as an interdisciplinary, experiential study, was to investigate the nature of the child.

Słowa kluczowe: pedologia, poznanie dziecka, dzieciństwo, psychologia eksperymentalna

Keywords: pedology, child recognition, childhood, experimental psychology

Dziecko i dzieciństwo jako kategoria społeczno-pedagogiczna badana i opisywana jest w literaturze pedagogicznej stosunkowo od niedawna. Systematyczna bowiem refleksja naukowa nad dzieciństwem sięga połowy XIX wieku i łączyła się z ówczesnym rozwojem psychologii dziecka (Matyjas 2012: 16), a następnie pedologii jako nauki o dziecku.

Przedmiotem referowanych badań jest rozwinięcie tezy, iż pedologia, kształtująca się w Europie i Stanach Zjednoczonych Ameryki od końca XIX wieku jako interdyscyplinarna, empiryczna nauka, której celem było poznanie natury dziecka, miała swoją genezę osadzoną w tradycji europejskiej pedagogii czasów nowożytnych, a szczególnie sięgających połowy XVIII wieku postulatach poznania dziecka.

Postulaty te wyrastały z zapoczątkowanego już w XVII wieku procesu ,odkrycia dziecka” i uszanowania odrębności dzieciństwa (Ariès 1995: 9 i nast., 130-132). Wcześniej bowiem, szczególnie w epoce średniowiecza, jak sądzi wielu historyków, dziecko było ledwie dostrzegalne. Philippe Ariès pisał, że w tych wiekach nie rozumiano specyfiki dzieciństwa, nie zdawano sobie sprawy z odrębności dziecka, którego postać również w ówczesnej sztuce, ignorowano (Teterycz-Puzio 2013: 257-258). W przedstawieniach artystycznych wyróżniał je tylko mały wzrost. W piśmiennictwie, w kronikach średnio- 
wiecznych, głównie z XI-XIV wieku, powstałych w Polsce oraz w krajach sąsiednich, pojawiają się jednak informacje dotyczące dzieciństwa książąt i świętych (Tamże: 260 i nast.). Dorota Żołądź-Strzelczyk w książce pt. „Dziecko w dawnej Polsce” (2002:12), zaprzecza twierdzeniom o braku zainteresowań dzieckiem w średniowieczu, podając fakty, że w tej epoce, szczególnie małe dziecko, znajdowało się w zasięgu uwagi ówczesnej medycyny i prawa, a niektórzy myśliciele epoki wśród faz życia człowieka, dostrzegali także okres dzieciństwa (Żołądź-Strzelczyk 2002: 20-21).

Twierdzeniom Philippe'a Arièsa, które na wiele lat zaciążyły na rozwoju historycznych badań nad dzieciństwem, szczególnie tych dotyczących braku postrzegania dziecka jako istoty różnej od dorosłego oraz o obojętności emocjonalnej dorosłych wobec dziecka, przeczą współczesne ustalenia badawcze mediewistów (Brzeziński 2012: 143). Niemniej prekursorska w swoim czasie (lata $60 . \mathrm{XX}$ wieku) książka P. Arièsa będzie nadal miała swoje miejsce w historiografii dzieciństwa, przede wszystkim ze względu na wkład francuskiego badacza w uhistorycznienie kategorii dziecka i dzieciństwa oraz ustalenia dotyczące postrzegania i stosunku dorosłych wobec dzieci w stuleciach następujących po średniowieczu.

Wówczas to, zdaniem P. Arièsa, „rodzina zaczyna się organizować wokół dziecka, które nabiera znaczenia, przestaje być anonimowe" (Ariès 1995: 9). Wraz z tymi przemianami od początku XVII wieku pojawia się w krajach Europy Zachodniej literatura pedagogiczna na użytek rodziców i wychowawców. U jej podstaw leżało nowe przekonanie, iż wychowanie dziecka jest jednym z pierwszych obowiązków dorosłych. „Wychowanie dzieci jest jedną z najważniejszych spraw na świecie” pisał Varet, autor „Edukacji chrześcijańskiej" (tamże: 117, 216). Ówczesne poradniki dla rodziców, niekiedy osobno adresowane do matek i ojców, były swoistymi instrukcjami, dotyczącymi ich obowiązków względem dzieci i zbiorem porad, jak się z nimi obchodzić. Taki charakter miały pierwsze poradniki wychowania dzieci: J.A. Komeńskiego, J. Locke'a, Ch. Coustela i Vareta. Spośród wymienionych, pierwszeństwo należy oddać Janowi Amosowi Komeńskiemu i jego „Szkole dzieciństwa, czyli o przewidującym wychowaniu dzieci w pierwszych sześciu latach" (1633), w której czeski pedagog w prostych słowach radził, jak rodzice powinni dziecku ukazywać świat w całym jego bogactwie" (Komeński 1956: XI-XII). Jako pierwszy w epoce nowożytnej J.A. Komeński zachęcał rodziców do podjęcia systematycznej troski o wychowanie dzieci.

W kolejnym stuleciu, w oświeceniowej Europie, w kręgach ówczesnych elit społecznych, zyskiwał na znaczeniu pogląd, iż dzieciństwo należy traktować jako czas i etap rozwoju człowieka i uczenia się ról (Matyjas 2012: 17). Duże znaczenie w takim postrzeganiu dzieciństwa mieli wówczas John Locke i Jan Jakub Rousseau (Postman 2001: 104). Pierwszy przekonywał, że dziecko rodzi się jak czysta karta, a wychowanie i kształcenie ma tę pustkę wypełnić. „Na tej podstawie kształtowała się koncepcja rozwoju dziecka rozumiana jako uczenie i kierowanie rozwojem" (Matyjas 2012: 17). Z kolei J.J. Rousseau twierdził, że „dziecko przychodzi na świat z darem natury i wieloma nieskażonymi cnotami” (tamże), a wychowanie ma chronić dziecko przed niszczącymi wpływami świata. 
W „Emilu” (1762) J.J. Rousseau przedstawiał dziecko jako odrębny byt i wartość samą w sobie. Na kartach tego swoistego traktatu-powieści twierdził, iż wychowanie winno być poprzedzone poznaniem dziecka. Sam autor głęboko wierzył w słuszność tej idei pisząc, iż „Tym właśnie badaniom oddałem się z największą pilnością, ażeby można było korzystać z moich spostrzeżeń nawet, gdyby cała moja metoda była urojona i fałszywa" (Rousseau 1955: 4). Do rodziców zaś apelował: „Kochajcie dzieciństwo (...), pozwólcie dzieciom radować się istnieniem" (tamże: 68).

Inspirowani tą ideą Jan Henryk Pestalozzi i niemiecki lekarz Dietrich Tiedeman pod koniec XVIII wieku dokonali pierwszych zapisów życia psychicznego własnych dzieci. Powstały dzienniki obserwacyjne rozwoju dzieci w pierwszych latach ich życia: J.H. Pestalozziego „Dziennik o wychowaniu własnego syna” (1774) i D. Tiedemana „Spostrzeżenia nad rozwojem władz duchowych dzieci” (1787), jako arkusz sporządzony na podstawie obserwacji rozwoju własnych dzieci w pierwszych latach ich życia. Oba dzienniki stanowiły pierwsze biografie psychologiczne dziecka i były niewątpliwą inspiracją w kierunku tworzenia przyszłej refleksji na temat wychowania rodzinnego. W pisanym pod koniec swojego życia - swoistym testamencie pedagogicznym - „Łabędzim śpiewie” (1826) J.H. Pestalozzi, stwierdzał, podobnie jak wcześniej J.J. Rousseau, iż wychowawca w wyniku poznania dziecka, winien uwzględniać jego indywidualność oraz dostosowywać do niej metodę swojego działania, wspomagając naturalny rozwój dziecka (Pestalozzi 1972: XV). Z kolei w innej swej pracy pt. „Moje badania nad biegiem natury w rozwoju ludzkości" (1791) szwajcarski pedagog sformułował tezę, iż człowiek powtarza w swoim rozwoju osobniczym rozwój gatunku. $Z$ tezy tej wyprowadzał założenie metodologiczne, iż można badać rozwój społeczeństwa badając rozwój własnej natury, można też studiując historyczny rozwój gatunku, poznać ewolucję własnej osobowości (tamże: XXI).

Od połowy XIX wieku dzienniki obserwacyjne stały się coraz bardziej popularne. Najczęściej cytowanym był wówczas „Szkic biograficzny o dziecku” Charlesa Darwina opublikowany w periodyku „Mind” w 1877 roku. Uczony ten przypisywał szczególne znaczenie obserwacji dzieci w wieku niemowlęcym i poniemowlęcym, ze względu na ich naturalny sposób reagowania na bodźce. W innej pracy pt. „O wyrazie uczuć u człowieka i zwierząt" (1872) Ch. Darwin omawiał kwestionariusz służący do prowadzenia obserwacji ruchów mimicznych oraz gestów dzieci.

Opierając się na obserwacjach Ch. Darwina, dokonanych podobnie jak te XVIII-wieczne na własnych dzieciach oraz pięciu innych biografiach niemieckich z lat 70. XIX wieku, polski pisarz i autor poradników - Henryk Wernic, opublikował w „Ateneum” (1879: 484-511), rozprawę pt. „Biografia dziecka”. W pracy tej, wspominając ustalenia badawcze wielu ówczesnych autorów biografii dziecięcych, sformułował prawidłowości rozwoju dziecka od urodzenia do 2-3 roku życia. Jest to bodaj pierwsza polska synteza psychologii rozwoju małego dziecka adresowana do rodziców, których H. Wernic zachęcał do czynienia podobnych spostrzeżeń na własnych dzieciach. Był przekonany, iż badając życie dziecka, dorośli zbiorą wiele spostrzeżeń „służących do kierowania dalszym 
jego wychowaniem” (Wernic 1879: 511). Wtedy, pisał H. Wernic, „to wychowanie zmieni się w prawdziwą sztukę, a wychowawca stanie się badaczem" (tamże).

W nauce zachodniej najbardziej znane były wówczas prace Wilhelma Preyera, głównie „Dusza dziecka” (1882) oraz „Wskazówki do czynienia obserwacji dla rodziców” (1895). Te ostatnie, jak większość ówczesnych, były oparte na obserwacji własnych dzieci. On również usilnie zachęcał rodziców do prowadzenia badań, gdyż jak sądził, obserwacje dzieci mogą stać się cennym materiałem do formułowania naukowych wniosków.

Te i wiele innych ówczesnych studiów nad dzieckiem nie wykroczyły poza fazę gromadzenia danych, najczęściej jednak rozproszonych i nie zawsze użytecznych. Choć jakość analiz i opisów, dokonywanych najczęściej przez „amatorów” - czyli rodziców, często nie była satysfakcjonująca naukowo, to jednak najważniejszy był fakt zainteresowania wielu ówczesnych rodziców własnymi dziećmi i możliwościami ich poznawania.

Poszukując genezy pedologii należy sięgnąć do dziejów polskiej pedagogiki i wydobyć z niesłusznego zapomnienia „Chowannę” (Poznań 1842) Bronisława Ferdynanda Trentowskiego. Pierwszą jej część autor zatytułował „Niepiotyką” - czyli nauką o dziecku. On również kładł nacisk na konieczność poznania duszy dziecka, wychodząc z założenia, że pedagogika oprzeć się powinna na psychologii, antropologii i innych naukach. Pisał: „poznanie zdolności i usposobień duszy w naszym wychowańcu jest rzeczą wielkiej wagi, gdyż pozwoli stan rzeczywistości dobrze poznanej kształcić i usposobieniu przyzwoity nadać kierunek" (Trentowski 1970). Jego wywody na temat natury dziecka stanowiły niewątpliwe źródło inspiracji dla przyszłych poczynań badawczych pedologów, których był bez wątpienia promotorem, czyniąc dziecko ośrodkiem wszelkich dociekań pedagogicznych.

W okresie romantyzmu, którego B.F. Trentowski był przedstawicielem, również literatura piękna zwracała uwagę na bogactwo życia uczuciowego dziecka, a ówczesne refleksje i wskazówki wychowawcze zalecały poznawanie natury dziecka i liczenie się z nią. „Wielka jest władza pierwszych wrażeń (...), im młodsze dziecię, tym większa jest jego jaźni potęga" (tamże), pisał Trentowski.

Kategoria dzieciństwa w dyskursie romantycznym, inspirowana poglądami J.J. Rousseau, wskazywała, że dzieci ucieleśniają stan niewinności, czystości i naturalnej dobroci. Dopiero kontakt ze zdeprawowanym światem zewnętrznym może je zepsuć. Po autorze „Emila” - twierdzi historyk literatury Maria Piwińska, romantycy odziedziczyli filozoficzne i emocjonalne przekonanie o szczególnej wartości dzieciństwa. Emocjonalny stosunek romantyków wobec dziecka wyrażał się w używanych porównaniach. Dziecko dla romantyków „było aniołkiem, listkiem, kwiatkiem, płomykiem, motylkiem, gołąbkiem. Opisywano je najczulszymi słowami” (Piwińska 1981: 15; Sobczak 1992: 103).

Druga połowa XIX wieku dzięki wprowadzeniu na coraz szerszą skalę badań eksperymentalnych, wytworzyła korzystny klimat dla rozwoju wielu dziedzin wiedzy. Wówczas to postulat wiązania oddziaływań pedagogicznych z poznawaniem wychowanka, zwłaszcza jego „natury”, stał się wiodącą ideą pedagogii pozytywistycznej. Ideolog polskiego pozytywizmu, Aleksander Świętochowski podkreślał wówczas, że charakterystyczną ce- 
chą nowoczesnej myśli humanistycznej, jest to, że zajmuje się dzieckiem. Wyrazem tej tendencji były zainicjowane od lat 70. XIX wieku badania nad rozwojem psychicznym dziecka w różnych sferach jego rozwoju. Kształtowała się wówczas, najbardziej rozwinięta w Stanach Zjednoczonych, psychologia dziecka. Ówcześni psycholodzy próbowali technikami badań empirycznych określić poziom rozwoju dziecka przychodzącego do szkoły oraz zasób pojęciowy dzieci i rozwój ich mowy. Analizy zachowań dziecka oparte na obserwacji dokonywali W. Perez, A. Binet i E. Claparède. Autorytetem dla amerykańskich i europejskich, w tym polskich badaczy - empirystów był Stanley Hall (1904), organizator wielkiego kongresu psychologii dziecięcej w 1892 r. w Chicago.

Wraz z podejmowaniem studiów, doskonalono metodologię badań nad rozwojem dzieci, poszukując jednocześnie źródeł ich poznawania. Carl Barnes, profesor pedagogii w Uniwersytecie Laland Stanford, wskazał m.in. na następujące:

- obserwacje planowane i okolicznościowe,

- „rozbiór” własnych wspomnień z dzieciństwa,

- „dzienniki wrażeń” i korespondencje uczniów,

- rysunki i inne wytwory twórczości dziecięcej,

- biografie małych dzieci,

- eksperymenty psychologiczne,

- ankiety opracowywane za pomocą metod statystycznych (Adamek 2005: 16).

Postępowały wówczas badania nad procesami rozumowania dzieci, pomiarami inteligencji oraz diagnostycznością i prognostycznością testów.

W nauce polskiej, równolegle do ówczesnych badań zachodnich, kompleksowe badania nad rozwojem dziecka zapoczątkował Jan Władysław Dawid swym oryginalnym dziełem „Program postrzeżeń psychologiczno-wychowawczych nad dziećmi” (Warszawa 1887). Zamieszczony tam nowatorski szczegółowy kwestionariusz oraz jego testy obrazkowe z „Zasobu umysłowego dziecka” (1885) dobrze służyły poznaniu dziecka, które miało być podstawą oddziaływań wychowawczych. Sam J.W. Dawid i zespół redagowanego przez niego „Przeglądu Pedagogicznego” w 1886 r. systematycznie kierował apele do psychologów, pedagogów, nauczycieli i rodziców pod hasłem ,poznajmy nasze dzieci”. Warto tu dodać, że podstawowym założeniem pedagogicznym J.W. Dawida stał się tytuł opublikowanego w 1882 r. artykułu pt. „Wychowawcy powinni znać prawa rządzące ciałem i duszą". Dla wielu ówczesnych pedagogów, w tym także twórczyni polskiej koncepcji wychowania przedszkolnego - Marii Weryho-Radziwiłłowiczowej, dewizą było hasło głoszone przez Eduarda Claparede’a, że „,dziecko ma być laboratorium, a nie audytorium" (tamże: 19).

Tym wszystkim działaniom sprzyjało, upowszechniając wiedzę o dziecku, powstałe 24 kwietnia 1907 roku w Warszawie Polskie Towarzystwo Badań nad Dziećmi. Jego założycielka i pierwsza przewodnicząca, uczennica J.W. Dawida, Aniela Szycówna, wielokrotnie podkreślała fakt praktycznej wartości psychologiczno-pedagogicznych studiów nad dzieckiem. Na przełomie XIX i XX wieku pojawiło się wiele prac popularno-naukowych i poradnikowych, w tym medycznych, higienicznych i dietetycznych, kierowanych 
do rodziców. Praktyka wychowawcza coraz szerzej czerpała z wyników ówczesnych badań naukowych (Jakubiak 2000: 113-132), które z kolei służyły wychowaniu w rodzinie, powszechnie wówczas uznanemu jako doniosłe zagadnienie społeczne tych czasów. Tym samym uznawano doniosłość zadań wychowawczych stojących przed rodzicami (Adamek 2005: 20).

Ruch „nowego wychowania” kształtujący się równolegle w Europie Zachodniej i Stanach Zjednoczonych Ameryki na przełomie XIX i XX wieku, lansując pajdocentryczną ideę szacunku dla dziecka, jeszcze bardziej wzmógł intensywność zajęcia się problematyką dziecka. Twórcy tego ruchu zamierzali wytyczać nowe kierunki badań w tym zakresie (Wnęk 2012: 9-13). Pisano wówczas „Emancypacja dziecka dokonywa się w oczach naszych z gwałtowną szybkością. Sprzyjają temu badania uczonych, określających naturę, siły i możliwości wieku dziecięcego" (Z.J. 1929: 9). Pajdocentryzm wiązał się z postulatem coraz dokładniejszego poznawania wychowanka. Było to wiązanie dialektyczne. Dzięki rozwojowi biologii i psychologii następowało zrozumienie dziecięcych przeżyć, zbliżenie do dziecięcego świata, które wyzwalało dla problemów i potrzeb świata uczucie szacunku. Z kolei szacunek dla świata nakazywał głębsze wnikanie w specyfikę dziecięcej natury i jej potrzeby.

Jeden z najbardziej reprezentatywnych polskich pajdocentrystów - Janusz Korczak, w jednej ze swoich wczesnych prac pt. „Jak kochać dziecko” - stwierdzał i przestrzegał: „Nie znamy dziecka, gorzej - znamy je z przesądów. Aż wstyd, jak na dwa trzy dzieła pisane naprawdę przy kołysce, powołują się aż do obrzydzenia wszyscy" (Korczak 1978: 251). Janusz Korczak, uznając działalność praktyczną za najbogatsze źródło wiedzy o dzieciach, postulował, by poznawać je przez oddziaływanie wychowawcze. Jednocześnie dobitnie podkreślał, że dziecko powinno być badane, poznawane jako całość. Wynikało to z jego przekonania o nierozerwalnej spójności psychiki, umysłu i uczuć oraz zdrowia psychicznego i fizycznego człowieka (Miska 1978: 158; Szemińska 1978: 167). Korczak marzył o „wielkiej syntezie” wiedzy o dziecku i jego zachowaniu. Jako lekarz, stosując obserwację kliniczną, poznawał poszczególne dzieci i ich zachowanie. Podkreślając ich indywidualność, szukał jednocześnie prawidłowości. Widział potrzebę wypracowania na gruncie pedagogiki diagnostyki wychowawczej, opartej na rozumieniu objawów (Korczak 1978: 212).

Prekursorzy europejskiej pedologii wywodzący się z głośnych wówczas laboratoriów psychologicznych: Lipska, Genewy i Brukseli, szukając prawidłowości rozwoju dziecka ustalali wskaźniki jego biologicznego, intelektualnego i społecznego rozwoju (Smolińska-Theiss 2014: 43), służące diagnozie.

Jeszcze przed I wojną światową przyswojono polskiej literaturze psychologiczno-pedologicznej najważniejsze prace psychologów europejskich, co stało się czynnikiem inspirującym do podejmowania własnych tematów i eksperymentów (Meissner 2011: 142). Polskie badania nad dzieckiem najsilniej rozwinęły się wówczas w zaborze rosyjskim i w Galicji i dorównywały poziomem badaniom zachodnioeuropejskim. Największe zaś dokonania, spośród polskich uczonych, w tej dziedzinie mieli wówczas: Jan Władysław 
Dawid, Józefa Joteyko, Aniela Szycówna, Władysław Heinrich, Bolesław Błażek i Józef Ciembroniewicz. Obok działalności w zakresie upowszechniania wiedzy o dziecku i sposobach badania jego osobowości, sami również prowadzili oryginalne badania w następujących dziedzinach:

- antropometrii;

- fizjologii;

- inteligencji i pamięci;

- procesów myślenia;

- charakterologii;

- rozwoju uczuć moralnych oraz stosunku dzieci do otaczającego świata, w tym do świata przyrody, ale także np. stosunku dzieci do wojny (Tamże: 146-156).

Polska pedologia, podobnie jak i zachodnia, zarówno w swym holistycznym paradygmacie, jak i w późniejszym okresie atomizacji, eksponowała potrzebę wielostronnego poznania dziecka, prawidłowości kierujących jego rozwojem, uwarunkowań oraz występujących zaburzeń w celu zastosowania tej wiedzy w praktyce wychowawczej. Pedologia utwierdziła nowożytne tendencje traktowania dziecka jako człowieka, aktywnego podmiotu poznania naukowego, a także nośnika i dysponenta informacji o sobie i innych dzieciach.

Dorobek pedologii, będący rezultatem wielu szczegółowych badań i nadzieje, jakie z nią wiązano, wyzwalały u wielu pedagogów przesadne ambicje i roszczenia, by nauka o dziecku zajęła miejsce dawnej pedagogii i ówczesnej pedagogiki, której zmierzch chętnie wówczas ogłaszano. Zarzucano jej, że: „cierpi na brak podstaw naukowych, ma charakter raczej literacki, wywody jej są ogólnikowe; nie jest to nauka lecz sztuka wychowania" (Lipska-Librachowa 1910: 116). Maria Lipska-Librachowa, podobnie jak inne prekursorki polskiej pedologii, w swej programowej rozprawie na jej temat, akcentowała dążenie pedologii do naukowości poprzez celowe wybranie doświadczalnych metod poznawania dziecka i praktyczne zastosowanie w taki sposób zdobywanej wiedzy. Tak rozumianą pedologię uznawała za aktualny w pierwszych dekadach XX wieku etap rozwoju i ewolucji pedagogiki.

\section{Literatura}

Adamek I. (2005), Wkład teoretyków i praktyków obcych i polskich w rozwój badań psychologicznych nad dzieckiem na przetomie XIX i XX wieku. „Annales Academiae Paedagogicae Cracoviensis" Folia 29.

Ariès P. (1995), Historia dzieciństwa. Dziecko i rodzina w dawnych czasach. Gdańsk, Marabut.

Brzeziński W. (2012), Obraz dziecka w perspektywie historyczno-porównawczej. Przeszłość we wspótczesności, współczesność w przeszłości. „Przegląd Pedagogiczny”, nr 1.

Hall S. (1904), Znaczenie studiów nad dziećmi. Warszawa.

Jakubiak K. (2000), Edukacja rodziców w polskiej teorii i praktyce pedagogicznej XIX i XX wieku - do 1939 roku. W: K. Jakubiak, A. Winiarz (red.), Wychowanie w rodzinie polskiej od schytku XVII do połowy XX wieku. Zbiór studiów. Bydgoszcz, Wydawnictwo WSP. 
Komeński J.A. (1956), Wielka dydaktyka. Wrocław, PAN.

Korczak J. (1978), Jak kochać dziecko. W: J. Korczak, Pisma wybrane, t. I. Warszawa, Nasza Księgarnia.

Korczak J. (1978), Momenty wychowawcze. W: J. Korczak, Pisma wybrane. t. III, Warszawa, Nasza Księgarnia.

Lipska-Librachowa M. (1910), Pedologia, czyli pedagogika naukowa. „Wychowanie w Domu i Szkole", z. 2.

Matyjas B. (2012), Dzieciństwo jako kategoria historyczna i społeczno-pedagogiczna. Próba syntezy. W: E. Kula, M. Pękowska (red.), Virginibus puerisque, t. 2, Z zagadnień wychowania i opieki nad dzieckiem w XVIII-XX wieku. Kielce, Wydawnictwo Uniwersytetu Jana Kochanowskiego.

Meissner A. (2011), Wkład Galicji w rozwój badań nad dzieckiem. W: A. Winiarz (red.), W kręgu oświaty, szkolnictwa i nauki. Księga pamiątkowa dedykowana Profesorowi Karolowi Poznańskiemu. Lublin, I - F Drukarnia Bogusława Karzyńska-Woźniak.

Miska H. (1978), Działalność praktyczna jako główne źródło wiedzy Janusza Korczaka o dziecku. W: Janusz Korczak - życie i dzieło: materiały z Międzynarodowej Sesji Naukowej. Warszawa, 12-18 października 1978.

Pestalozzi P.H. (1972), Pisma pedagogiczne. Wstęp i oprac. R. Wroczyński. Wrocław, Ossolineum.

Piwińska M. (1981), Złe wychowanie, fragmenty romantycznej biografii. Warszawa, Państwowy Instytut Wydawniczy.

Postman N. (2001), W stronę XVIII stulecia. Jak przeszłość może doskonalić nasza przyszłość. Warszawa, Państwowy Instytut Wydawniczy.

Rousseau J.J. (1955), Emil, t. I. Wrocław, Zakład Narodowy im. Ossolińskich.

Smolińska-Theiss B. (2014), Korczakowskie narracje pedagogiczne. Kraków, Oficyna Wydawnicza Impuls.

Sobczak J. (1992), Przejawy zainteresowania wychowaniem rodzinnym w pracach niektórych polskich pisarzy i pedagogów u schyłku XVIII $i$ w pierwszej połowie XIX wieku. „Studia Pedagogiczne", z. 18.

Szemińska A. (1978), Korczak jako psycholog. W: Janusz Korczak-życie i dzieło: materiały z Międzynarodowej Sesji Naukowej. Warszawa, 12-18 października 1978.

Teterycz-Puzio A. (2013), Dziecko i dzieciństwo w świetle wybranych źródel narracyjnych (do $X I V$ w.). „Studia Gdańskie”, t. XXVIII.

Trentowski B.F. (1970), Chowanna, czyli system pedagogiki narodowe jako umiejętności wychowania, nauki i oświaty, słowem wykształcenia naszej młodzieży. T. 1. Wrocław, Zakład Narodowy im. Ossolińskich.

Wernic H. (1879), Biografia dziecka. „Ateneum” t. III.

Wnęk J. (2012), Dziecko w polskiej literaturze naukowej 1918-1939. Warszawa, Oficyna Wydawnicza ASPRA-JR.

Z.J. (1929), Co wiemy o dziecku? „Młoda Matka”, nr 23.

Żołądź-Strzelczyk D. (2002), Dziecko w dawnej Polsce. Poznań, Wydawnictwo Poznańskie. 